\title{
ECONOMIC THEORY OF CLUSTER DEVELOPMENT OF A REGION WITH A HIGH VALUE OF PETROCHEMICAL COMPLEX
}

\author{
Beilin I.L. \\ $\mathrm{PhD}$ in Economics, Kazan Federal University, Institute of Management, Economics and Finance, \\ 8 Kremlyovskaya Street, Kazan 420008, Russian Federation. \\ Email: i.beilin@rambler.ru
}

Article History: Received on $15^{\text {th }}$ July 2019, Revised on $30^{\text {th }}$ August 2019, Published on $18^{\text {th }}$ September 2019

Abstract

Purpose: The purpose of this study is to develop the theory of regional economics in the context of the cluster organization of its petrochemical complex.

Methodology: The research methodology includes the use of cluster analysis and network planning of performance indicators of the petrochemical complex of the Republic of Tatarstan.

Findings: It was found that over seven years of the existence of petrochemical cluster in the Republic of Tatarstan, no synergistic effects were achieved because of its activities. At the same time, significant financial resources were allocated to the cluster organization of petrochemical complex in this region and an administrative apparatus was created. The very concept of cluster development of the region in science and practice has long proved its viability in many countries, such as the Republic of Tatarstan since Michael Porter. This is because the Soviet times is provided with a highly developed industrial base and inexpensive labor in the field of petrochemical technologies, and the training of professional specialists in the region is provided by a concentration of higher education institutions.

Implications: The economic and mathematical approaches used in this study enable it to single out the forms of activity in the cluster that enable it to increase its efficiency to the greatest extent with the least costs. Comprehensive network planning of cluster innovation based on graphical and potential methods presented in the study provide competitive advantages to small- and medium-sized companies.

Keywords: Economics, Econometrics, Economic and Mathematical Modeling, Economic Theory, Regional Economy, Innovation Management.

\section{INTRODUCTION}

The main thesis of Michael Porter is that promising competitive advantages are not created from outside, but from domestic markets. In the course of his research, Michael Porter analyzed the competitive opportunities of more than 100 industries in ten countries. It turned out that the most competitive transnational companies were usually not scattered haphazardly across countries, but were concentrated in one country, and sometimes even in one region of a country (Dimitras, Slowinski, Susmaga \& Zopounidis, 1999; Rose, 2001; Zimmerman, 2001). It is a fact that one or several firms reach competitiveness in the world market and extend the positive influence on the nearest environment of suppliers, consumers, and competitors. The success of the environment has an impact on the further growth of the company's competitiveness.

As a result, a "cluster" is formed, where a community of firms and closely related industries contribute to the mutual growth of competitiveness. Clusters play the role of growth points in the domestic market for the entire state economy. Following the first, new clusters are often formed and international competitiveness of a country increases as a whole. It rests precisely on the strong positions of individual clusters, whereas even the most developed economy can produce mediocre results outside of them. The benefits are distributed in all areas of relations in the cluster.

New producers coming from other industries accelerate their development, stimulating research and development and providing necessary funds for introducing new strategies. There is a free exchange of information and the rapid spread of innovations through channels of suppliers or consumers who have contacts with numerous competitors. Interconnections within the cluster, often completely unexpected, lead to the emergence of new ways of competition and generate completely new opportunities. People, resources, and ideas form new combinations.

In general, there are three broad definitions of clusters, each of which emphasize the main feature of its functioning:

- These are regionally limited forms of economic activity within the related sectors, usually tied to one or the other scientific institution (research institutes, universities, etc.). 
- These are vertical production chains and rather narrowly defined sectors, in which the adjacent stages of the production process form the core of the cluster (for example, the chain of "supplier-producer-marketer-client"). The networks that form around the parent companies fall into this category.

- These are industries identified at a high level of aggregation (for example, a "chemical cluster") or a combination of sectors at an even higher level of aggregation (for example, an "agro-industrial cluster"). Speaking of clusters, there are two strategies that complement each other:

- Strategies aimed at increasing the use of knowledge in existing clusters.

- Strategies aimed at creating new networks of cooperation within the clusters.

\section{METHODS}

Over time, effectively operating clusters become the cause of large investments and close attention of the government, i.e., a cluster becomes something more than a simple sum of its individual parts. Most often, the center of the cluster is formed by several powerful companies that maintain competitive relations between them. This makes the cluster different from a cartel or a financial group (Dimova, Sevastjanov \& Sevastianov, 2001; Zadeh, 2001; Inuiguchi \& Tanino, 2001; Zopounidis \& Oth, 2002). The concentration of rivals and their buyers and suppliers contributes to the growth of effective specialization of production. At the same time, the cluster also provides jobs for many small firms and small enterprises. In addition, the cluster form of organizations leads to the creation of a special form of innovation the "total innovative product". Clustering based on vertical integration forms not only a spontaneous concentration of various scientific and technological inventions, but a certain system of dissemination of new knowledge and technologies. At the same time, the most important condition for effective transformation of inventions into innovations and of innovations into competitive advantages is the formation of a network of stable links among all cluster members. Thus, although cooperation is becoming necessary, it carries with it a known danger - the possibility of loss of independence (the ability of an independent line of conduct in the market for independent development of new products, new technologies, etc.).

That is why a number of countries have recently emphasized on effective "cluster strategies", which are built on business centers that have already proven their strength and competitiveness in the global market (Isard \& Hara, 2002; Isard, 2004; Isard, 2005; Porter \& Kramer, 2006). Governments are focusing on supporting existing clusters and creating new networks of companies that have not previously contacted each other. At the same time, the state not only promotes the formation of clusters, but also becomes a participant in the networks itself. Cluster strategies are widely used in Europe.

For example, biotech clustering program has been in operation in Germany since 1995. In Britain, the government identified areas around Edinburgh, Oxford, and Southeast England as the main regions to locate biotech firms. In Norway, the government encourages cooperation between firms in the "maritime economy" cluster. Finland has a developed timber cluster, which includes the production of wood and wood products, paper, furniture, printing, and related equipment. The close cooperation of firms in this cluster in the dissemination of knowledge provides them with competitive advantages over their main trading rivals.

\section{RESULTS AND DISCUSSION}

Cluster principles for organizing production and enhancing cooperation at the regional level are much more widespread in post-socialist countries. This approach provides great opportunities to increase the competitiveness of local businesses and increase the effectiveness of the regional authorities' economic policy. Currently, a cluster-based approach to regional development is becoming practically active. Since 1998, the first regional clusters were created and operated in Ukraine, which comprised clusters of sewing enterprises, agricultural and processing enterprises, and construction companies, and manufacturers of building materials.

Their functioning has led to positive structural changes in the region, the most important being the change in investment climate (Porter, 2008; Edward E. Leamer, 2008; Isard \& Han, 2008; Uziel Sandler, Lev Tsitolovsky, 2008; Erdal Kayacan, 2009). The cluster approach is increasingly used in developing regional development strategies. For example, the joint Russian-Finnish project "Long-Term Strategy for the Development of the Economy of St. Petersburg" is being implemented in St. Petersburg since 2000 (Yves, 2010). The theoretical basis of the study is the model of "diamond" by Michael Porter. Consequently, an analysis was conducted in the branches of urban economy, their interconnections were revealed, and competitors were identified. At the same time, factors, such as the existing structure of non-payments, receivables and payables, depreciation of fixed assets, availability of labor resources, ability to attract investments, etc., were taken into account. As a result, a model of main urban clusters was created. There are nine urban clusters in St. 
Petersburg, namely, power engineering, shipbuilding and ship repair, food, transport, tourism, woodworking, software and information technology, optical instrumentation, and metallurgy.

A global trend has emerged wherein companies are concentrated on the main lines and the production of intermediate products and the scope of key services are delegated to others, including small enterprises. Given this trend, the creation of clusters has a powerful impact on small businesses. As for our country, the effective restructuring of former "industrial giants" requires deep interaction and cooperation among large businesses, small businesses, government, universities, research institutes, etc. The cluster approach provides the necessary tools and analytical methodology (Crowther \& Haimes, 2010; Porter \& Kramer, 2011; Wang, 2011; Zobel, 2012; Corrado \& Fingleton, 2012; Fisher \& LeSage, 2013). The use of cluster approach allows achieving extended development of small- and medium-sized businesses.

However, irrespective of the importance of motivations for clustering, the organization of such cooperation is far from simple for small firms, which tend to flourish through individualism and enterprise. Therefore, working too closely with competitors, suppliers, or customers can be a real threat for such firms.

The financial sector and education were not included in this list, as they did not reach the cluster by their indicators. Shipbuilding, ship repair, and woodworking were attributed to the potential type of clusters due to the "ineffective institutional structure" and the lack of targeted state policy on their formation.

An example of the cluster development of a region with a high value of the petrochemical complex is the Nizhny Novgorod Region, the Republic of Bashkortostan, and the Republic of Tatarstan (Figure 1).

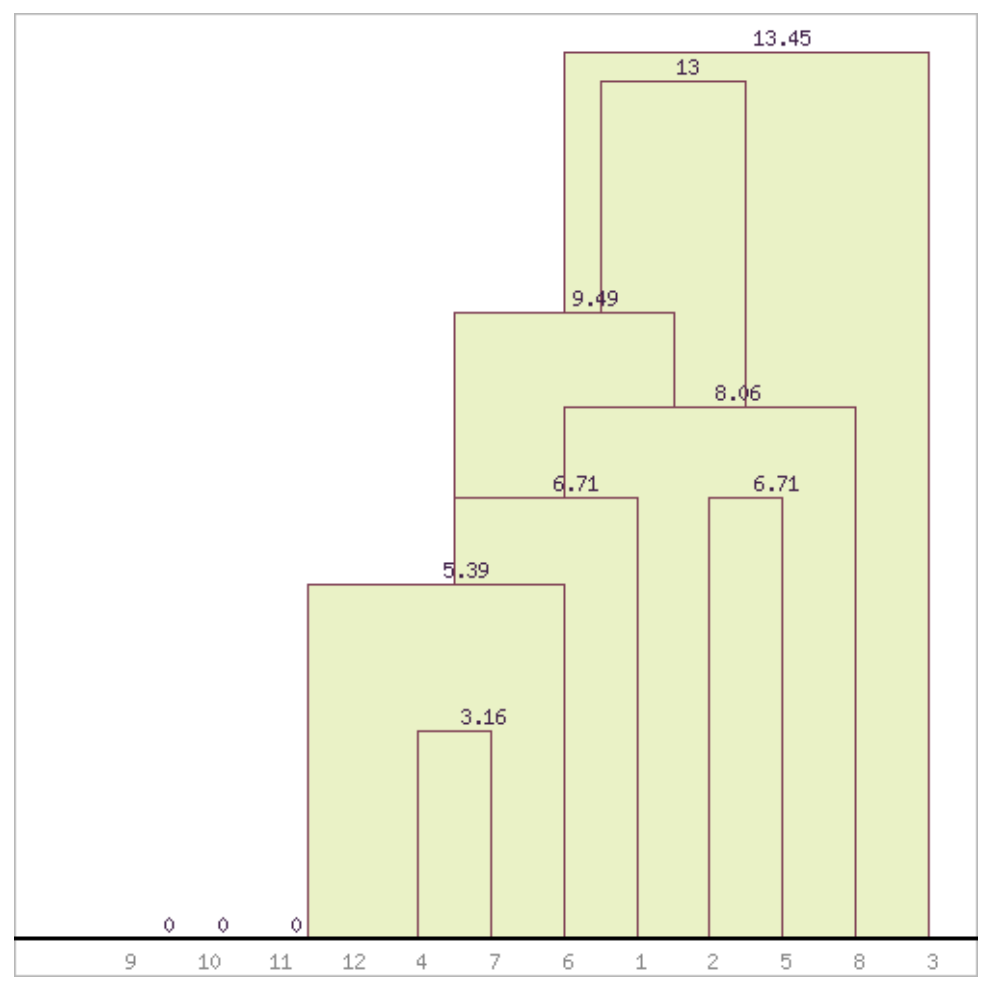

Figure 1: An example of a cluster analysis of exports of the petrochemical complex of the Republic of Tatarstan in 2015-2017

An important distinguishing feature of the cluster is its innovative orientation. The most successful clusters are formed where a "breakthrough" is taking place in the field of engineering and production technology or are expected with the subsequent entry into new "market niches". In this regard, many economically developed and developing countries are increasingly using the "cluster approach" in shaping and regulating their national innovation programs (Porter \& Heppelmann, 2014; Porter \& Heppelmann, 2015; Chen, Xiaohong \& Pouzo, 2015; Porter \& Heppelmann, 2017). For example, the task of forming and strengthening regional innovation clusters in the United States was set as one of the most important national priorities in the Competitiveness Council report.

The main slogan of the American innovation policy is "investing in technology is investing in America's future." At the same time, special attention is paid to the definition and support of those innovations that ensure long-term business development (Figures 2 and 3). Four main forms of state innovation policy, namely, direct budget support for the development and implementation of new technologies and products; indirect support through tax policy and 
administrative regulation; investment in the education system; and support of critical elements of the economic infrastructure for the advancement of innovation, can be distinguished.

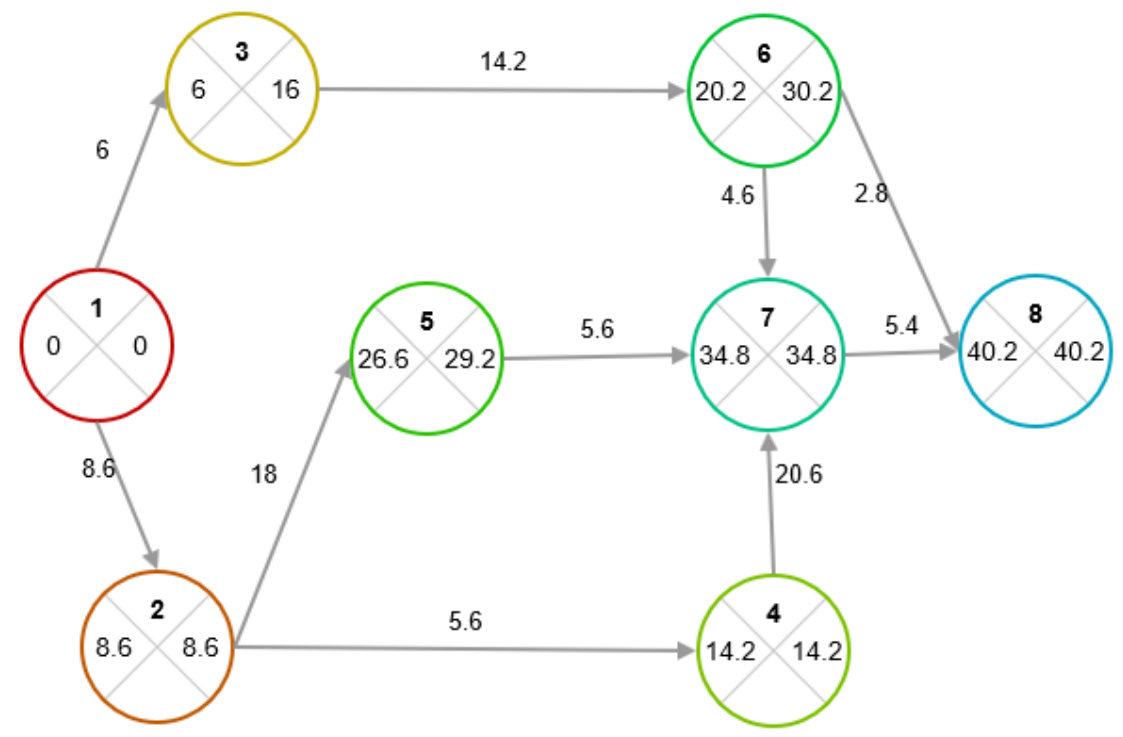

Figure 2: An example of a solution in a graphical way (sectoral method) of network planning for cluster development of a region with an innovative petrochemical complex

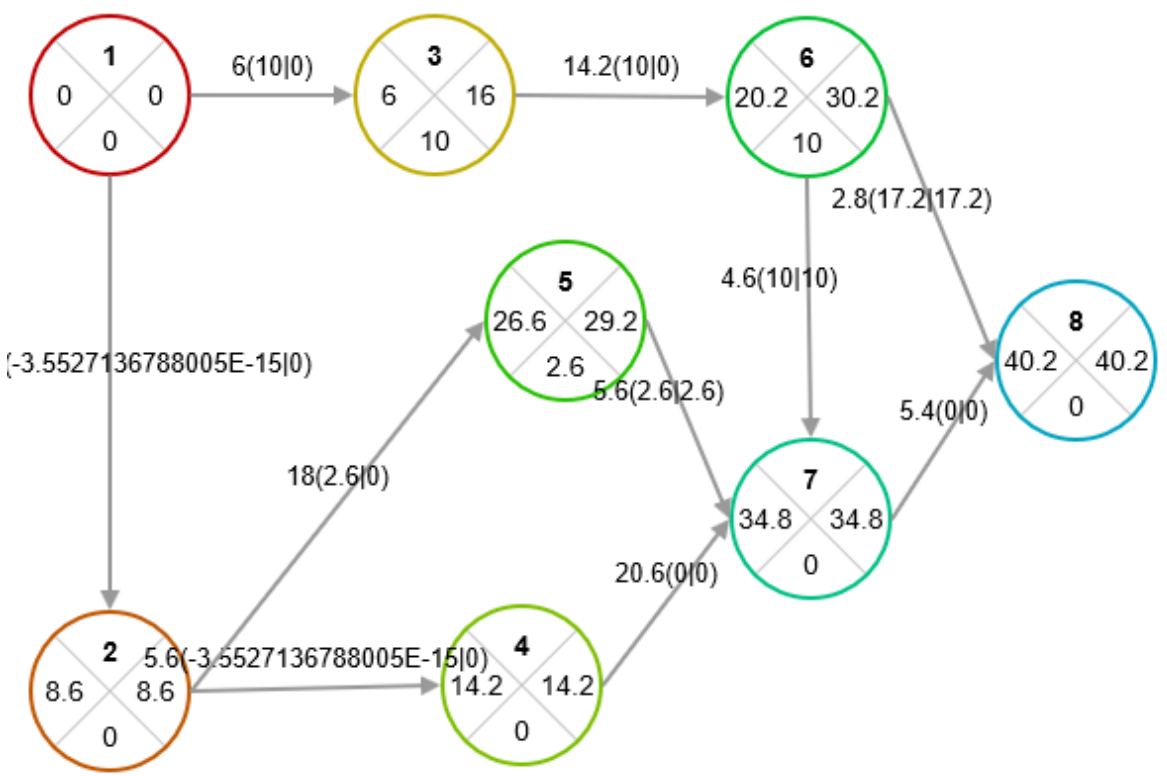

Figure 3: An example of a solution using the potential of network planning for cluster development of a region with an innovative petrochemical complex

It should be noted that the cluster approach provides an excellent basis for creating new forms of knowledge pooling (Beilin, 2017; Beilin \& Khomenko, 2018). Cluster-oriented industrial policies stimulate the emergence of "new combinations" and indirectly support them, especially in the field of education and research, as well as through promotional intermediary centers. For example, cooperation programs, such as Eureka, play an important role at the European level. They bring together potential partners who have failed to find the additional knowledge they need at the local level. Of course, a large role in the formation of new combinations is played by large demonstration programs.

\section{CONCLUSIONS}

Foreign experience shows that in large developed economies, most cluster initiatives that have been active in the past few years have been put forward by local or regional governments. In smaller developed countries and in many developing countries, national governments play an important role in cluster development initiatives, especially where local and regional governments fail to be a true private sector partner. In countries where centralized decision-making is the norm, many decisions on clusters are made at the national level. 
The following factors determine the increasing influence of the state of clustering processes: market failure, growing importance and volume of public goods, an objective priority of public interests in the context of globalization, and the need to protect national business in world economic relations.

\section{SUMMARY}

The analysis of foreign experience in the formation of cluster policy led to the following conclusions:

1) There are national features of cluster policy;

2) There are a variety of strategic cluster alternatives, which are determined by national peculiarities and the adopted cluster concept;

3) Cluster policies of states differ in the degree of government intervention in the clustering process;

4) The methodological basis for the formation of cluster policy has not been developed.

\section{ACKNOWLEDGEMENT}

The work is performed according to the Russian Government Program of Competitive Growth of Kazan Federal University.

\section{BIBLIOGRAPHY}

1. Dimitras A.I., Slowinski R., Susmaga R., Zopounidis C. Business Failure Prediction Using Rough Sets // European Journal of Operational Research, p. 114, 1999.

2. Rose P.R. Risk Analysis and Management of Petroleum Exploration Ventures American Association of Petroleum Geologists, Methods in Exploration Series, 2001. Pp. 234-245.

3. Zimmerman H.-J. Fuzzy Sets Theory -and Its Applications. -Kluwer Academic Publishers, pp. 123-145. 2001.

4. Dimova L., Sevastjanov P., Sevastianov D. Fuzzy Capital Budgeting: Investment Project Valuation and Optimization // Chenstohova Tech. Univercity Proceedings, pp. 451-467. 2001.

5. Zadeh L. Toward a perception-based theory of probabilistic reasoning with imprecise probabilities//Journal of Statistical Planning and Inference 105 (2002) Pp. 233-264.

6. Inuiguchi M., Tanino T. Portfolio selection under independent possibilistic information//Fuzzy sets and systems. 2001. V. 115. Pp. 83-92.

7. Zopounidis C. and Oth. Fuzzy Sets in Management, Economy and Marketing /Ed. - World Scientific Pub Co, pp. 264-271. 2002.

8. Isard, W., and Hara, T. (2002). "The Old City of Jerusalem as a Tourist International Magnet: An Initial Proposal for a First Step Cooperation in the Middle East." Peace Economics, Peace Science and Public Policy Vol. 8, No. 4, pp. 46-59.

9. Isard, W. (2004). «A Jordan/West Bank Development Proposal». Peace Economics, Peace Science and Public Policy Vol. 10, Issue. 2, Article 2. Pp. 54-67.

10. Isard, W. (2005) Industry-Services Complex Analysis for Poverty Region Development (Realistic Development Theory for Regions Emerging from Poverty), Peace Economics, Peace Science and Public Policy, Volume 11, Issue 1, ISSN (Online) 1554-8597, DOI: https://doi.org/10.2202/1554-8597.1081.

11. Porter, M.E. \& Kramer, M.R. (2006) "Strategy and Society: The Link between Competitive Advantage and Corporate Social Responsibility", Harvard Business Review, pp. 78-92. 2006.

12. Porter, M.E. (2008) "The Five Competitive Forces That Shape Strategy", Harvard Business Review, January 2008, pp. 79-93.

13. Edward E. Leamer (2008). "Specification problems in econometrics," The New Palgrave Dictionary of Economics. Abstract. Archived 23 September 2015 at the Wayback Machine. Pp. 35-64.

14. Isard, W., Han, S.H., (2008), Mediation Analysis: The Use of Regional Science Methods to Resolve Conflicts, Peace Economics, Peace Science and Public Policy, vol. 13, no. 2, pp. 1-13.

15. Uziel Sandler, Lev Tsitolovsky. Neural Cell Behavior and Fuzzy Logic. Springer, 2008. Pp. 478 - 495.

16. Erdal Kayacan, Ph.D. Candidate. Contributions to Type-2 Fuzzy Sets. Theory and Applications in Control Engineering and Robotics. - 2009.- № 10. Pp. 149-163.

17. Tardy Yves, Petrology of Laterites and Tropical Soils. ISBN 90-5410-678-6, http://www.books.google.com/books. Retrieved April 17, 2010. Pp. 224-245. 
18. Crowther K.G., Haimes Y.Y. Development of the Multiregional Inoperability Input-Output Model (MRIIM) for Spatial Explicitness in Preparedness of Interdependent Regions//Systems Engineering Vol. 13, No. 1, 2010. Pp. 124-143.

19. Porter, M.E. \& Kramer, M.R. (2011) "Creating Shared Value", Harvard Business Review, Jan/Feb 2011, Vol. 89 Issue $1 / 2$, pp. 62-77.

20. Hua Wang. Fuzzy Control Systems Design and Analysis: A Linear Matrix Inequality Approach, 2011. Pp. 273296.

21. Zobel C.W., L. Khansa Quantifying Cyberinfrastructure Resilience against Multi-Event Attacks//Decision Sciences Vol. 43 No. 4, 2012. Pp. 184-195.

22. Corrado L., Fingleton B. (2012). Where is the Economics in Spatial Econometrics? Journal of Regional Science, 52 (2), Pp. 210-239.

23. Fisher M., LeSage J. (2013). A Bayesian space-time approach to identifying and interpreting regional convergence clubs in Europe. Paper presented at 53rd ERSA conference, Palermo, Pp. 27-31.

24. Porter, M.E. \& Heppelmann, J.E. (2014) "How Smart, Connected Products are Transforming Competition", Harvard Business Review, November 2014, pp. 65-88.

25. Porter, M.E. \& Heppelmann, J.E. (2015) "How Smart, Connected Products are Transforming Companies", Harvard Business Review, October 2015, pp. 97-114.

26. Chen, Xiaohong and Demian Pouzo (2015): Sieve Wald and QLR inferences on semi/nonparametric conditional moment models, Econometrica, 83, pp. 1013-1079.

27. Porter, M.E. \& Heppelmann, J.E. (2017) "Why Every Organization Needs an Augmented Reality Strategy", Harvard Business Review, November 2017, pp. 46-62.

28. Beilin I.L. Economic-mathematical modeling of the total costs of innovative chemical enterprise methods of fuzzy set theory // Journal of Engineering and Applied Sciences, 2017, Volume 12, Issue 19, 4865-4869.

29. Beilin I.L. Economic optimization in chemical enterprises // International Journal of Economic Perspectives, 2017, Volume 11, Issue 4, 670-677.

30. Beilin I.L., Khomenko V.V. Theoretical bases of project management in conditions of innovative economy based on fuzzy modeling // Journal of Physics: Conference Series 1015 (2018) 032013 doi :10.1088/1742$6596 / 1015 / 3 / 032013$. 